\title{
DETERMINAN INTERNAL DIVIDEND PAYOUT RATIO PERUSAHAAN FARMASI TERDAFTAR DI BURSA EFEK INDONESIA
}

\author{
Zulkifli, Endri, Augustina Kurniasih \\ Program Magister Manajemen Universitas Mercu Buana \\ Jl. Raya Meruya Selatan No.1 Kembangan Jakarta Barat, 11650, Indonesia
}

\begin{abstract}
Keywords: current ratio, return on assets, debt to equity ratio, dividend payout ratio, earning growth, earning per share, market to book value, return on equity

JEL Classification: B26, C01, C23

This study aimed to examine and analyze the effect of internal determinant of dividend payout ratio pharmaceutical company, annual data observation period 2008 until 2014. The type of this study was quantitative research. Population of the research was the entire pharmaceutical company consisting of 10 companies. The sampled criteria were pharmaceutical companies that consistently paid cash dividends. There were 6 companies listed in Indonesia Stock Exchange with non-probability sampling technique namely purposive sampling. Data analysis used panel data regression fixed effect which had larger $R$ square value. The results showed that current ratio, return on assets, debt to equity ratio, earnings growth, return on equity, earnings per share and market to book value simultaneously were having significant influence to the dividend payout ratio. Partially return on assets and market to book value had a positive significant effect on the dividend payout ratio, while current ratio, debt to equity ratio and return on equity had a significant negative effect. Earnings growth and earnings per share did not have significant influence on the dividend payout ratio. It was suggested to add external variables factors using more samples of companies.
\end{abstract}

Kata Kunci: current ratio, return on assets, debt to equity ratio, earning growth, return on equity, earning per share, market to book value, dividend payout ratio. 


\section{Determinan Internal Dividend Payout Ratio Perusahaan Farmasi terdaftar di Bursa Efek Indonesia Zulkifli, Endri, Augustina Kurniasih}

Kebijakan dividen mempunyai pengaruh bagi pemegang saham dan perusahaan. Para pemegang saham umumnya menginginkan pembagian dividen yang relatif stabil. Sementara perusahaan membutuhkan sumber dana untuk meningkatkan pertumbuhan untuk kelangsungan hidup perusahaan. Apabila perusahaan memilih untuk membagikan dividen, maka akan mengurangi laba yang ditahan dan mengurangi sumber dana internal. Sebaliknya jika perusahaan memilih untuk menahan laba dan tidak membayarkan dividen, maka kemampuan perusahaan membentuk dana internal akan semakin besar tetapi mengurangi kesejahteraan bagi pemegang saham. Sundjaja \& Barlin (2010) menyatakan bahwa kebijakan dividen merupakan sebuah keputusan yang diambil oleh perusahaan terkait dengan dividen, apakah laba akan dibagi kepada pemegang saham atau investor dalam bentuk dividen atau laba akan ditahan sebagai laba yang ditahan untuk pembiayaan investasi di masa yang akan datang.

Kebijakan dividen dipengaruhi faktor internal diantaranya posisi likuiditas perusahaan, kebutuhan dana untuk membayar utang, tingkat pertumbuhan perusahaan, pengawasan terhadap perusahaan (Riyanto, 2010). Profitabilitas juga mencerminkan kemampuan perusahaan memperoleh laba yang memiliki hubungan dengan penjualan, total aktiva maupun modal sendiri. Dengan demikian bagi investor jangka panjang akan sangat berkepentingan dengan analisis profitabilitas ini misalnya bagi pemegang saham akan melihat keuntungan yang benar-benar akan diterima dalam bentuk dividen (Sartono, 2010).

Literatur penelitian yang terkait dengan determinan internal dividend payout ratio yaitu Amah (2012), Harianja et al. (2013) dan Zulkifli (2015) menyatakan bahwa current ratio berpengaruh positif dan signifikan terhadap dividend payout ratio. Sebaliknya Odawo (2015), Mertayani et al. (2015) dan Sunarya (2013) menyatakan bahwa current ratio berpengaruh negatif dan signifikan terhadap dividend payout ratio. Hasil empiris yang berbeda dengan Rehman \& Takumi (2012), Maladjian \& Khoury (2014) dan Saeed et al (2014) menyatakan bahwa current ratio tidak berpengaruh terhadap dividend payout ratio. Sebaliknya Hossain et al. (2014), Rahayuningtyas et al. (2014) dan Laim et al. (2015) menyatakan bahwa current ratio tidak berpengaruh terhadap dividend payout ratio.

Marlina \& Danica (2009), Marpaung \& Hadianto (2009), Amah (2012), Rehman \& Takumi (2012), Halim (2013), Hutagalung et al. (2013), Sunarya (2013), Yudhanto \& Aisjah (2013), Hossain et al. (2014), Lioew (2014), Manneh \& Naser (2015), Odawo (2015), Khalid dan Rehman (2015) dan Zulkifli (2015) menyatakan bahwa return on asset berpengaruh positif dan signifikan terhadap dividend payout ratio. Sebaliknya Hasan et al. (2015) dan Utami (2015) menyatakan bahwa return on asset berpengaruh negatif dan signifikan terhadap dividend payout ratio. Hasil empiris yang berbeda dengan Laim et al (2015) menyatakan bahwa return on asset tidak berpengaruh terhadap dividend payout ratio. Sebaliknya Harianja et al (2013) dan Saeed et al (2014) menyatakan bahwa return on asset tidak berpengaruh terhadap dividend payout ratio.

Amah (2012), Rehman \& Takumi (2012), Marietta \& Sampurno (2013) dan Odawo (2015) menyatakan bahwa debt to equity ratio berpengaruh positif dan signifikan terhadap dividend payout ratio. Sebaliknya Laim et al. (2015), Mertayani et al. (2015) dan Zulkifli (2015) menyatakan bahwa debt to equity ratio berpengaruh negatif dan signifikan terhadap dividend payout ratio. Hasil empiris yang berbeda dengan Marlina \& Danica (2009) menyatakan bahwa debt to equity ratio tidak berpengaruh terhadap dividend payout ratio. Sebaliknya Utami (2015) menyatakan bahwa debt to equity ratio tidak berpengaruh terhadap dividend payout ratio.

Amah (2012), Maladjian \& Khoury (2014) dan Zulkifli (2015) menyatakan bahwa growth berpengaruh negatif dan signifikan terhadap dividen 


\section{Jurnal Keuangan dan Perbankan | KEUANGAN}

Vol. 21, No. 2, April 2017: 238-252

payout ratio. Hasil empiris yang berbeda dengan Hossain et al. (2014) menyatakan bahwa growth tidak berpengaruh terhadap dividend payout ratio. Sebaliknya Pribadi \& Sampurno (2012), Marietta (2013) dan Laim et al. (2015) menyatakan bahwa growth tidak berpengaruh terhadap dividend payout ratio.

Harianja et al. (2013), Yudhanto \& Aisjah (2013) dan Zulkifli (2015) menyatakan bahwa return on equity berpengaruh positif dan signifikan terhadap dividend payout ratio. Sebaliknya Maladjian \& Khoury (2014) menyatakan bahwa return on equity berpengaruh negatif dan signifikan terhadap dividend payout ratio. Hasil empiris yang berbeda dengan Lioew (2014) dan Rahayuningtyas et al. (2014) menyatakan bahwa return on equity tidak berpengaruh terhadap dividend payout ratio.

Yudhanto \& Aisjah (2013), Saeed et al. (2014) dan Zulkifli (2015) menyatakan bahwa earning per share berpengaruh positif dan signifikan terhadap dividend payout ratio. Sebaliknya Hasan et al. (2015) menyatakan bahwa earning per share berpengaruh negatif dan signifikan terhadap dividend payout ratio.

Marpaung \& Hadianto (2009) dan Utami (2015) menyatakan bahwa market to book value berpengaruh positif dan signifikan terhadap dividend payout ratio. Hasil empiris yang berbeda dengan Rehman \& Takumi (2012) dan Halim (2013) menyatakan bahwa market to book value tidak berpengaruh terhadap dividend payout ratio.

Penelitian ini bertujuan untuk mengestimasi dan menganalisis current ratio, return on assets, debt to equity ratio, earning growth, return on equity, earning per share, market to book value secara parsial terhadap dividend payout ratio. Penelitian ini diharapkan memberikan kontribusi terhadap dua hal. Hal pertama yaitu bagi teoritis dapat memberikan bukti empiris dan kontribusi secara ilmiah mengenai kandungan informasi keuangan internal perusahaan yang berpengaruh terhadap kebijakan dividen dan sebagai acuan dan referensi untuk mengembangkan variabel-variabel yang memengaruhi dividend payout ratio dan memberikan kontribusi dalam memperkaya penelitian-penelitian sebelumnya. Hal kedua yaitu bagi praktis dapat memberikan informasi dan rekomendasi pihak yang terkait khususnya bagi investor dapat menjadikannya sebagai dasar dalam pengambilan keputusan berinvestasi dan memperoleh hasil temuan yang memberikan masukan untuk perusahaan bahwa analisis kinerja keuangan sebagai salah satu faktor yang memengaruhi kebijakan dividen pada perusahaan farmasi.

\section{PENGEMBANGAN HIPOTESIS}

Likuiditas perusahaan merupakan salah satu pertimbangan utama dalam kebijakan dividen karena dividen bagi perusahaan merupakan arus kas keluar, maka semakin besar posisi kas dan likuiditas perusahaan secara keseluruhan akan semakin besar kemampuan perusahaan untuk membayar dividen (Sartono, 2010). Likuiditas diukur menggunakan proksi current ratio merupakan rasio likuiditas dengan membandingkan antara current assets dengan current liabilities untuk menggambarkan kemampuan perusahaan dalam menyelesaikan kewajiban jangka pendeknya. Rasio ini menunjukkan sejauh mana aktiva lancar menutupi kewajiban-kewajiban lancar (Harahap, 2008).

Literatur hasil empiris Amah (2012), Harianja et al. (2013) dan Zulkifli (2015) menyatakan bahwa current ratio berpengaruh positif dan signifikan terhadap dividend payout ratio. Posisi kas atau likuiditas perusahaan merupakan faktor yang penting yang harus dipertimbangkan sebelum mengambil keputusan untuk menetapkan besarnya dividen yang akan dibayarkan kepada para pemegang saham. Oleh karena dividen merupakan "cash outflow", maka semakin kuat posisi kas perusahaan berarti semakin besar kemampuan perusahaan untuk membayar dividen (Riyanto, 2010). Berdasarkan kajian empiris, maka hipotesis pertama yaitu: 


\section{Determinan Internal Dividend Payout Ratio Perusahaan Farmasi terdaftar di Bursa Efek Indonesia Zulkifli, Endri, Augustina Kurniasih}

$\mathrm{H}_{1}$ : diduga current ratio berpengaruh positif terhadap dividend payout ratio.

Profitabilitas adalah kemampuan perusahaan memperoleh laba yang memiliki hubungan dengan penjualan, total aktiva maupun modal sendiri. Profitabilitas diukur menggunakan proksi return on assets yang merupakan rasio yang mengukur kemampuan perusahaan secara keseluruhan di dalam menghasilkan keuntungan dengan jumlah seluruh aktiva yang tersedia didalam perusahaan, semakin tinggi rasio ini maka semakin baik keadaan suatu perusahaan (Syamsuddin, 2011).

Literatur hasil empiris Marlina \& Danica (2009), Marpaung \& Hadianto (2009), Amah (2012), Rehman \& Takumi (2012), Halim (2013), Hutagalung et al. (2013), Sunarya (2013), Yudhanto \& Aisjah (2013), Hossain et al. (2014), Lioew (2014), Manneh \& Naser (2015), Odawo (2015), Khalid \& Rehman (2015) dan Zulkifli (2015) menyatakan bahwa return on assets berpengaruh positif dan signifikan terhadap dividend payout ratio. Return on assets menunjukkan kemampuan modal yang diinvestasikan dalam total aktiva untuk menghasilkan laba perusahaan. Semakin tinggi return on assets, maka pembagian dividen juga semakin besar (Sartono, 2010). Dengan demikian bagi investor jangka panjang akan sangat berkepentingan dengan analisis profitabilitas ini misalnya bagi pemegang saham akan melihat keuntungan yang benar-benar akan diterima dalam bentuk dividen. Berdasarkan kajian empiris, maka hipotesis kedua yaitu:

$\mathrm{H}_{2}$ : diduga return on assets berpengaruh positif terhadap dividend payout ratio.

Leverage adalah penggunaan sumber dana yang memiliki beban tetap dengan harapan bahwa akan memberikan tambahan keuntungan yang lebih besar daripada beban tetapnya sehingga akan meningkatkan keuntungan yang tersedia bagi pemegang saham (Sartono, 2010). Leverage diukur menggunakan proksi debt to equity ratio yang meru- pakan rasio leverage yang menggambarkan hubungan antara utang perusahaan terhadap modal. Untuk keamanan pihak luar adalah rasio terbaik jika jumlah modal lebih besar dari pada jumlah utang atau minimal sama. Hal ini berarti bahwa perusahaan mampu mengukur seberapa jauh dibiayai oleh utang atau pihak luar dengan kemampuan perusahaan yang digambarkan oleh modal (equity) atau berapa percentage komposisi modal yang dimilikinya lebih besar dari utang (Harahap, 2008).

Literatur hasil empiris Laim et al. (2015), Mertayani et al. (2015) dan Zulkifli (2015) menyatakan bahwa debt to equity ratio berpengaruh negatif dan signifikan terhadap dividend payout ratio. Rasio utang dengan modal sendiri (debt to equity ratio) merupakan perimbangan antara utang yang dimiliki perusahaan dengan modal sendiri. Semakin tinggi rasio ini berarti modal sendiri semakin sedikit dibanding dengan utangnya. Semakin tinggi debt to equity ratio yang dimiliki suatu perusahaan maka perusahaan tersebut akan cenderung membagikan dividen dalam jumlah yang kecil pada pemegang sahamnya. Dengan semakin tingginya rasio ini perusahaan akan menggunakan laba yang akan diperolehnya untuk membayar kewajibannya dimasa yang lalu sehingga akan berdampak pada semakin kecilnya jumlah dividen yang akan dibagikan perusahaan (Sutrisno, 2009). Berdasarkan kajian empiris, maka hipotesis ketiga yaitu:

$\mathrm{H}_{3}$ : diduga debt to equity ratio berpengaruh negatif terhadap dividend payout ratio.

Pertumbuhan merupakan rasio yang menggambarkan kemampuan perusahaan mempertahankan posisi ekonominya di tengah pertumbuhan perekonomian dan sektor usahanya. Rasio pertumbuhan diantaranya: pertumbuhan penjualan, pertumbuhan laba bersih, pertumbuhan pendapatan per saham dan pertumbuhan dividen per saham. (Kasmir, 2012). Pertumbuhan diukur menggunakan proksi earning growth. Subramanyam 


\section{Jurnal Keuangan dan Perbankan | KEUANGAN}

Vol. 21, No. 2, April 2017: 238-252

\& Wild (2010) menyatakan bahwa laba (earning) atau laba bersih (net income) mengindikasikan profitabilitas perusahaan. Laba mencerminkan pengembalian kepada pemegang ekuitas untuk periode yang bersangkutan. Laba merupakan perkiraan atas kenaikan atau penurunan ekuitas sebelum distribusi kepada dan kontribusi dari pemegang ekuitas. Semakin tinggi tingkat pertumbuhan perusahaan, akan semakin besar tingkat kebutuhan dana untuk membiayai ekspansi. Semakin besar kebutuhan dana di masa yang akan datang, semakin memungkinkan perusahaan menahan keuntungan dan tidak membayarkannya sebagai dividen. Oleh karenanya, potensi pertumbuhan perusahaan menjadi faktor penting yang menentukan kebijakan dividen. Perusahaan dengan tingkat pertumbuhan tinggi lebih menyukai rasio pembayaran dividen yang rendah.

Literatur hasil empiris Amah (2012), Maladjian \& Khoury (2014) dan Zulkifli (2015) menyatakan bahwa growth berpengaruh negatif dan signifikan terhadap dividend payout ratio. Riyanto (2010) mengemukakan salah satu faktor yang memengaruhi dividen yaitu tingkat pertumbuhan. Semakin cepat tingkat pertumbuhan suatu perusahaan, semakin besar kebutuhan akan dana untuk membiayai pertumbuhan tersebut. Semakin besar kebutuhan dana untuk waktu mendatang untuk membiayai pertumbuhannya, perusahaan tersebut biasanya lebih senang untuk menahan pendapatannya daripada membayarkan sebagai dividen para pemegang saham dengan mengingat batasanbatasan biayanya. Semakin cepat tingkat pertumbuhan perusahaan makin besar dana yang dibutuhkan, semakin besar kesempatan untuk memperoleh keuntungan, semakin besar bagian dari pendapatan yang ditahan dalam perusahaan, berarti makin rendah dividend payout ratio. Berdasarkan kajian empiris, maka hipotesis keempat yaitu:

$\mathrm{H}_{4}$ : diduga earning growth berpengaruh negatif terhadap dividend payout ratio.
Profitabilitas selanjutnya menggunakan proksi return on equity yang merupakan rasio yang digunakan mengukur dari penghasilan atau income yang tersedia bagi para pemilik perusahaan (baik para pemegang saham biasa maupun preferen) atas modal yang mereka investasikan didalam perusahaan, semakin tinggi return atau penghasilan yang diperoleh semakin baik kedudukan pemilik perusahaan. Hal ini berarti perusahaan mampu mengukur dari penghasilan atau income yang tersedia bagi para pemilik perusahaan berapa percentage atas modal yang mereka investasikan. (Syamsuddin, 2011).

Literatur hasil empiris Harianja et al (2013), Yudhanto \& Aisjah (2013) dan Zulkifli (2015) menyatakan bahwa return on equity berpengaruh positif dan signifikan terhadap dividend payout ratio. Return on equity merupakan ukuran profitabilitas dari sudut pandang pemegang saham. Salah satu alasan utama perusahaan beroperasi adalah menghasilkan laba yang bermanfaat bagi para pemegang saham. Semakin besar return on equity mencerminkan kemampuan perusahaan dalam menghasilkan keuntungan yang tinggi bagi pemegang saham. Hal ini berdampak terhadap peningkatan dividen (Sartono, 2010). Berdasarkan kajian empiris, maka hipotesis kelima yaitu:

$\mathrm{H}_{5}$ : diduga return on equity berpengaruh positif terhadap dividend payout ratio.

Profitabilitas selanjutnya menggunakan proksi earning per share yang merupakan rasio pendapatan per lembar saham biasa karena hal ini menggambarkan jumlah rupiah yang diperoleh untuk setiap lembar saham biasa. Para calon pemegang saham tertarik dengan earning per share yang tinggi yang mengindikasikan keberhasilan suatu perusahaan. Hal ini berarti bahwa perusahaan mampu menghasilkan keuntungan yang akan didistribusikan bagi para pemegang saham biasa berapa rupiah atas jumlah saham beredar dan tergantung kebijakan perusahaan dalam pembayaran 


\section{Determinan Internal Dividend Payout Ratio Perusahaan Farmasi terdaftar di Bursa Efek Indonesia Zulkifli, Endri, Augustina Kurniasih}

dividen. (Syamsuddin, 2011). Berdasarkan kajian empiris, maka hipotesis keenam yaitu:

Literatur hasil empiris Yudhanto \& Aisjah (2013), Saeed et al. (2014) dan Zulkifli (2015) menyatakan bahwa earning per share berpengaruh positif dan signifikan terhadap dividend payout ratio. Brigham \& Houston (2006) mengemukakan keterkaitan antara earning per share terhadap dividen yaitu earning per share merupakan rasio yang menunjukkan bagian laba untuk setiap saham. Earning per share menggambarkan profitabilitas perusahaan yang tergambar pada setiap lembar saham. Semakin tinggi nilai earning per share akan menyebabkan semakin besar laba dan kemungkinan peningkatan jumlah dividen yang diterima pemegang saham. Berdasarkan kajian empiris, maka hipotesis keenam yaitu:

Tabel 1. Definisi Operasional dan Skala Pengukuran Variabel

\begin{tabular}{|c|c|c|}
\hline Variabel & Definisi Operasional & Pengukuran \\
\hline $\begin{array}{l}\text { Dependen : } \\
\text { Dividen Payout Ratio (Y) } \\
\text { Sartono (2010: 491) }\end{array}$ & $\begin{array}{l}\text { Dividen perlembar Saham } \\
\text { dibagi dengan laba } \\
\text { persaham }\end{array}$ & $\mathrm{DPR}=\frac{\text { Dividend Per Share }}{\text { Earning Per Share }} \times 100 \%$ \\
\hline $\begin{array}{l}\text { Independen: } \\
\text { Current } \\
\text { Ratio (X1) } \\
\text { Harahap (2008: 301). }\end{array}$ & $\begin{array}{l}\text { Aktiva lancar dibagi } \\
\text { dengan kewajiban lancar }\end{array}$ & $\mathrm{CR}=\frac{\text { Current Assets }}{\text { Current Liabilities }} \times 100 \%$ \\
\hline $\begin{array}{l}\text { Return on Asset (X2) } \\
\text { Syamsuddin ( 2011: 64). }\end{array}$ & $\begin{array}{l}\text { Laba bersih dibagi dengan } \\
\text { total aktiva }\end{array}$ & ROA $=\frac{\text { Net Profit After Tax }}{\text { Total Asset }} \times 100 \%$ \\
\hline $\begin{array}{l}\text { Debt to Equity Ratio (X3) } \\
\text { Harahap }(2008: 306)\end{array}$ & $\begin{array}{l}\text { Total kewajiban dibagi } \\
\text { dengan modal }\end{array}$ & $\frac{\text { Total Utang }}{\text { Modal }} \times 100 \%$ \\
\hline $\begin{array}{l}\text { Earning Growth (X4) } \\
\text { Harahap (2008: 309) }\end{array}$ & $\begin{array}{l}\text { Laba bersih tahun ini } \\
\text { dikurangi dengan laba } \\
\text { bersih tahun lalu dan } \\
\text { dibagi laba bersih tahun } \\
\text { lalu }\end{array}$ & $\mathrm{EG}=\frac{\text { Laba bersih }(t)-\text { Laba bersih }(-t)}{\text { Laba bersih }(-t)} \times 100 \%$ \\
\hline $\begin{array}{l}\text { Return on Equity (X5) } \\
\text { Syamsuddin ( 2011: 65) }\end{array}$ & $\begin{array}{l}\text { Laba bersih dibagi dengan } \\
\text { total modal }\end{array}$ & $\mathrm{ROE}=\frac{\text { Net Profit After Tax }}{\text { Stockholders Equity }} \times 100 \%$ \\
\hline $\begin{array}{l}\text { Earning Per Share (X6) } \\
\text { Syamsuddin (2011: 66). }\end{array}$ & $\begin{array}{l}\text { Laba bersih dibagi dengan } \\
\text { jumlah saham beredar di } \\
\text { transformasi ke (Ln) }\end{array}$ & $\mathrm{EPS}=\frac{\text { Earning Available for Common Stock }}{\text { Number of Shares of Common Stock out Standing }} \times \operatorname{Rp} 1$ \\
\hline $\begin{array}{l}\text { Market to Book Value (X7) } \\
\text { Harahap (2008: } 310)\end{array}$ & $\begin{array}{l}\text { Nilai pasar saham dibagi } \\
\text { dengan nilai buku }\end{array}$ & MTBV $=\frac{\text { Nilai Pasar Saham }}{\text { Nilai Buku }} \times 100 \%$ \\
\hline
\end{tabular}

Sumber: Dari berbagai Teori (2015). 


\section{Jurnal Keuangan dan Perbankan | KEUANGAN}

Vol. 21, No. 2, April 2017: 238- 252

$\mathrm{H}_{6}$ : diduga earning per share berpengaruh positif terhadap dividend payout ratio.

Market Value to Book Value Ratio (MB) juga merupakan ukuran yang menarik dari kinerja karena menunjukkan perbedaan antara aset bersih perusahaan dan valuasi dari nilai pasar yang diinginkan investor. Artinya, rasio mencerminkan premium (atau diskon) bahwa pasar mencerminkan nilai aktiva bersih perusahaan dan juga menunjukkan efisiensi dimana pasar memandang bagaimana perusahaan dikelola. Premi tinggi menunjukkan bahwa setiap rupiah tambahan diinvestasikan dalam aset bersih perusahaan akan menghasilkan imbal hasil yang menarik bagi para investor; sebaliknya, premi yang rendah menunjukkan bahwa pengembalian investasi tambahan menjadi mungkin menarik. Dengan demikian, konsisten dengan logika dalam kertas asli Tobin, rasio MB mencerminkan insentif untuk tambahan investasi modal demi pertumbuhan perusahaan (Tong dan Ruer, 2006; Goranova et al., 2010; Lenox et al., 2010).

Market Value to Book Value Ratio (MB) mencerminkan pandangan pasar dari nilai ekuitas dibandingkan dengan apa yang telah dikontribusikan pemegang saham kepada perusahaan. Menurut Omran \& Pointon (2004) menunjukkan bahwa MB merupakan faktor penting yang memengaruhi dividend payout ratio dan Amidu \& Abor (2006) menemukan hubungan negatif antara MB dengan dividend payout ratio. Gill et al. (2010) menemukan sebaliknya bahwa market to book value ratio memengaruhi dividend payout ratio secara positif. Berdasarkan kajian empiris, maka hipotesis ketujuh yaitu:

$\mathrm{H}_{7}$ : diduga market to book value berpengaruh negatif terhadap dividend payout ratio.

\section{METODE}

Desain penelitian adalah penelitian kausal untuk mengetahui pengaruh satu variabel atau lebih antara variabel bebas (independent variable) terhadap variabel terikat (dependent variable).

Metode pengumpulan data dalam penelitian ini adalah metode kepustakaan dengan cara membaca, mengamati, mencatat dan mempelajari dengan cara mengumpulkan data yang diperlukan melalui sumber-sumber tertulis seperti uraian teori dalam buku-buku, jurnal- jurnal, modul perkuliahan yang berhubungan dengan masalah yang diteliti serta mengunduh data dan informasi dari situssitus internet yang relevan.

Populasi penelitian adalah seluruh perusahaan farmasi yang tercatat di Bursa Efek Indonesia (BEI) berjumlah 10 (sepuluh). Teknik pengambilan sampel dalam penelitian ini dengan purposive sampling. Berdasarkan kriteria diperoleh 6 (enam) Perusahaan farmasi dalam sampel penelitian yang ditunjukkan dalam Tabel 2.

Tabel 2. Sampel Penelitian

\begin{tabular}{lc}
\multicolumn{1}{c}{ Perusahaan } & Kode \\
\hline PT Darya-Varia Laboratoria Tbk & DVLA \\
PT Kalbe Farma Tbk & KLBF \\
PT Kimia Farma Tbk & KAEF \\
PT Merck Tbk & MERK \\
PT Taisho Pharmaceutical Indonesia Tbk & SQBB \\
PT Tempo Scan Pasific Tbk & TSPC \\
\hline
\end{tabular}

Sumber: Bursa Efek Indonesia Periode 2008 -2014 (2015).

Penelitian ini menetapkan perusahaan farmasi sebagai sampel yang konsisten selama tahun pengamatan dan konsisten menbagikan dividen tunai periode 2008-2014.

Metode analisis data yang digunakan dalam penelitian ini adalah analisis regresi data panel yang merupakan gabungan data time series dan cross section. Ada tiga pendekatan dalam menganalisis regresi data panel yaitu Pooled Least Square, Fixed Effect dan Random Effect. Pemilihan Model Data Panel sebagai berikut: (a) Uji Chow adalah pengujian yang dilakukan untuk mengetahui apakah model yang digunakan adalah pooled least square atau fixed 


\section{Determinan Internal Dividend Payout Ratio Perusahaan Farmasi terdaftar di Bursa Efek Indonesia}

Zulkifli, Endri, Augustina Kurniasib

Tabel 3. Hasil Uji Model

\begin{tabular}{lrrr}
\hline \multicolumn{1}{c}{ Effects Test } & Statistic & d.f. & Prob. \\
\hline Cross-section F & 2,752960 & $(5,29)$ & 0,0374 \\
Test Summary & Chi-Sq. Statistic & Chi-Sq. d.f. & Prob. \\
Cross-section random & 5,027741 & 7 & 0,6566 \\
\hline
\end{tabular}

effect. (b) Uji Hausman digunakan untuk menentukan apakah menggunakan fixed effect atau random effect. (c) Lagrange Multiplier (LM) digunakan sebagai pertimbangan dalam pemilihan pendekatan antara pooled least square atau random effect.

Model regresi yang dibentuk diuji melalui: (a) Uji Koefisien Determinasi yang dinotasikan dengan $R^{2}$ digunakan sebagai uji statistik inferensial untuk kebaikan dari kesesuaian model (goodness of fit) yang mengukur berapa persentase variasi menjelaskan besarnya pengaruh semua variabel bebas terhadap variabel terikat. $R^{2}$ memilih range antara $0 \leq R^{2} \leq 1$. Jika $R^{2}$ bernilai 1 , maka garis regresi menjelaskan $100 \%$ variasi dalam variabel terikat. Sebaliknya jika $R^{2}$ sama dengan 0 maka garis regresi tidak menjelaskan variasi dalam variabel terikat. (b) Uji Signifikansi Simultan (F) dilakukan untuk melihat signifikansi pengaruh secara bersama-sama variabel independen dalam model terhadap variabel dependen. (c) Uji Signifikansi Parsial (t) dilakukan dengan nilai statistik untuk melihat signifikansi pengaruh individu dari variabel independen dalam model regresi terhadap variabel dependen. Kemudian dilanjutkan dengan mengestimasi persamaan regresi data panel.

\section{HASIL}

\section{Hasil Perhitungan Uji Masing- masing Model}

Metode regresi data panel yang digunakan dalam penelitan ini didasarkan atas tiga model yaitu: pooled least square, efek tetap (fixed effect) dan efek random (random effect). Model mana yang akan digunakan dalam penelitian ini untuk dianalisis lebih lanjut, maka akan dilakukan uji berpasangan untuk masing-masing model.
Berdasarkan Tabel 3, menunjukkan nilai probabilitas F test 0.037 lebih kecil dari $\alpha=0,05$, maka $\mathrm{H}_{0}$ ditolak dan $\mathrm{H}_{\mathrm{a}}$ diterima yang berarti bahwa model fixed effect lebih baik digunakan dalam mengestimasi regresi data panel dibandingkan model pooled least square dan dilanjutkan dengan uji Hausman test yang menunjukkan nilai probabilitas chi-square test 0.657 lebih besar dari $\alpha$ $=0,05$, maka $\mathrm{H}_{0}$ diterima dan $\mathrm{H}_{\mathrm{a}}$ ditolak yang berarti bahwa model random effect lebih baik digunakan dalam mengestimasi regresi data panel dibandingkan model fixed effect. Kemudian dilanjutkan dengan uji Chi-Square Lagrange Multiplier test sebagai berikut:

$$
\text { LM hitung }=\mathrm{LM}=[6(7): 2(7-1)] \times[49(0.027310) \text { : }
$$$$
0.646410)-1]^{2}=
$$

$\left[3.50[(1.338206: 0.646410)-1]^{2}=\left[3.50[(2.070212-1)]^{2}=\right.\right.$ $\left[3.50[(1.070212)]^{2}=[3.50(1.145353)]=4.009\right.$

Ket:Tabel chi-square, dengan á $=0,05$, dan $\mathrm{df}=\mathrm{n}$ $1=5$, yaitu $=11.071$

Dengan demikian model yang terbaik digunakan adalah pooled least squares karena nilai Chi-Square Lagrange Multiplier test sebesar 4.009 lebih kecil dari pada nilai chi-square tabel sebesar 11.071. Namun kesimpulan pengujian model ini setelah dilakukan dengan pengujian 3 (tiga) model, kemudian dilanjutkan untuk memilih model dengan membandingkan nilai $R$-squared $\left(R^{2}\right)$ yaitu pooled least squares sebesar $78.9 \%$, fixed effect sebesar $85.7 \%$ dan random effect sebesar $44.7 \%$. Hal ini berarti nilai $R$-squared yang lebih tinggi akan dianalisis lebih lanjut adalah model fixed effect untuk mengestimasi determinan internal dividend payout ratio perusahaan farmasi terdaftar di Bursa Efek Indo- 
nesia periode 2008-2014. Perhitungan Model regresi yang ditunjukkan pada Tabel 4 .

\section{Estimasi Model Regresi Data Panel Secara Bersama-sama}

Berdasarkan perhitungan pada Tabel 1.4, menunjukkan uji goodness-of-fit yang diukur dengan koefisien diterminasi $\left(R^{2}\right)$ menunjukkan nilai sebesar $85.7 \%$, artinya bahwa variasi perubahan baik naik maupun turunnya dividend payout ratio perusahaan farmasi dapat dijelaskan oleh variabel current ratio, return on asset, debt to equity ratio, earning growth, return on equity, earning per share dan market to book value. Sedangkan sisanya yaitu nilai sebesar $14.3 \%$ dijelaskan oleh variabel-variabel lain yang tidak tercakup dalam model penelitian ini. Pengujian signifikansi secara bersama-sama menunjukkan nilai F-statistic 14.504 dengan nilai probabilitas 0.000 lebih kecil dari á $=0.05$. Hal ini berarti $\mathrm{H}_{0}$ ditolak dan $\mathrm{H}_{\mathrm{a}}$ diterima sehingga dapat dinyatakan bahwa current ratio, return on asset, debt to equity ratio, earning growth, return on equity, earning per share dan market to book value secara bersamasama memengaruhi dividend payout ratio dengan tingkat keyakinan sebesar 95 persen.

\section{Estimasi Model Regresi Data Panel Secara Parsial}

Hasil estimasi determinan internal dividend payout ratio perusahaan farmasi terdaftar di Bursa Efek Indonesia periode 2008 - 2014 menggunakan model fixed effect seperti yang ditunjukkan dalam Tabel 1.5, dapat ditulis dalam bentuk persamaan, sebagai berikut:
$\mathrm{DPR}=0.705 \mathrm{C}-0.041 \mathrm{CR}+2.044 \mathrm{ROA}-0.379$ DER - 0.003 EG - 1.897 ROE + 0.022 EPS + $0.018 \mathrm{MTBV}$

\section{PEMBAHASAN \\ Pengaruh Current Ratio terhadap Dividend Payout Ratio}

Current ratio memengaruhi dividend payout ratio perusahaan farmasi secara negatif dan signifikan. Hasil empiris yang berbeda dengan penelitian Amah (2012), Harianja et al. (2013) dan Zulkifli (2015) menyatakan bahwa current ratio berpengaruh positif dan signifikan terhadap dividend payout ratio. Hasil empiris juga yang berbeda dinyatakan oleh Sartono (2010) bahwa current ratio merupakan

Tabel 4. Hasil Estimasi Model Regresi Data Panel

\begin{tabular}{|c|c|c|c|c|c|c|c|c|c|}
\hline \multirow[b]{2}{*}{ Variabel } & \multicolumn{3}{|c|}{ PLS } & \multicolumn{3}{|c|}{ FEM } & \multicolumn{3}{|c|}{ REM } \\
\hline & Coeff. & t-Stat. & Prob. & Coeff. & t-Stat. & Prob. & Coeff. & t-Stat. & Prob. \\
\hline Constants & 0,537 & 3,253 & 0,003 & 0,705 & 3,268 & 0,003 & 0,473 & 2,257 & 0,031 \\
\hline Current Ratio & $-0,077$ & $-2,745$ & 0,010 & $-0,041$ & $-2,659$ & 0,013 & $-0,051$ & $-1,689$ & 0,100 \\
\hline Return on Asset & 1,910 & 1,602 & 0,118 & 2,044 & 2,739 & 0,010 & 2,056 & 2,081 & 0,045 \\
\hline Debt Equity Ratio & $-0,681$ & $-4,381$ & 0,000 & $-0,379$ & $-2,041$ & 0,050 & $-0,579$ & $-2,979$ & 0,005 \\
\hline Earning Growth & $-0,099$ & $-2,664$ & 0,012 & $-0,003$ & $-0,155$ & 0,878 & $-0,075$ & $-2,277$ & 0,029 \\
\hline Return on Equity & $-1,239$ & $-1,129$ & 0,267 & $-1,897$ & $-3,726$ & 0,001 & $-1,506$ & $-1,685$ & 0,101 \\
\hline Earning Per Share & 0,082 & 6,196 & 0,000 & 0,022 & 1,009 & 0,321 & 0,072 & 6,307 & 0,000 \\
\hline Market to Book Value & 0,010 & 0,296 & 0,769 & 0,018 & 3,726 & 0,001 & 0,070 & 1,348 & 0,187 \\
\hline R-squared & 0,78 & & & 0,857 & & & 0,447 & & \\
\hline F-statistic & 18,20 & & & 14,504 & & & 3,930 & & \\
\hline Prob. & $(0,000$ & & & $(0,000)$ & & & $0,003)$ & & \\
\hline
\end{tabular}




\section{Determinan Internal Dividend Payout Ratio Perusahaan Farmasi terdaftar di Bursa Efek Indonesia Zulkifli, Endri, Augustina Kurniasih}

perbandingan antara aktiva lancar dengan utang lancar. Semakin tinggi current ratio, semakin besar kemampuan perusahaan dalam membayar dividen. Namun hasil empiris ini sama dengan Sunarya (2013), Mertayani et al. (2015) dan Odawo (2015) menyatakan bahwa current ratio berpengaruh negatif dan signifikan terhadap dividend payout ratio. Temuan empiris ini berarti current ratio semakin tinggi yang disebabkan meningkatnya assets lancar lebih besar dibandingkan dengan peningkatan utang lancar, kemungkinan laba bersih yang dihasilkan perusahaan farmasi lebih besar dialokasikan laba ditahan untuk membiayai assets lancar, maka semakin kecil dividen yang dibayarkan kepada para pemegang saham.

\section{Pengaruh Return on Assets terhadap Dividend Payout Ratio}

Return on assets memengaruhi dividend payout ratio perusahaan farmasi secara positif dan signifikan. Hasil empiris ini yang sama dengan Marlina \& Danica (2009), Marpaung \& Hadianto (2009) Amah (2012), Rehman \& Takumi (2012), Halim (2013), Hutagalung et al. (2013), Sunarya (2013), Yudhanto \& Aisjah (2013), Hossain et al. (2014), Lioew (2014), Manneh \& Naser (2015), Odawo (2015), Khalid \& Rehman (2015) dan Zulkifli (2015) menyatakan bahwa return on asset berpengaruh positif dan signifikan terhadap dividend payout ratio. Hasil empiris ini juga sama dengan Sartono (2010) menyatakan bahwa return on assets menunjukkan kemampuan modal yang diinvestasikan dalam total aktiva untuk menghasilkan laba perusahaan. Semakin tinggi return on asset, maka pembagian dividen juga semakin banyak. Temuan empiris ini berarti return on assets semakin tinggi yang disebabkan laba bersih perusahaan farmasi semakin meningkat yang diperoleh dari penggunaan assets perusahaan, maka semakin tinggi dividen yang dibayarkan kepada para pemegang saham.

\section{Pengaruh Debt to Equity Ratio terhadap Dividend Payout Ratio}

Debt to equity ratio memengaruhi dividend payout ratio perusahaan farmasi secara negatif dan signifikan. Hasil empiris ini yang sama dengan Laim et al. (2015), Mertayani et al (2015) dan Zulkifli (2015) menyatakan bahwa debt to equity ratio berpengaruh negatif dan signifikan terhadap dividend payout ratio. Hasil empiris ini juga sama dengan Sutrisno (2009) menyatakan bahwa rasio utang dengan modal sendiri (debt to equity ratio) merupakan imbangan antara utang yang dimiliki perusahaan dengan modal sendiri. Semakin tinggi rasio ini berarti modal sendiri semakin sedikit dibanding dengan utangnya. Semakin tinggi debt to equity ratio yang dimiliki suatu perusahaan maka perusahaan tersebut akan cenderung membagikan dividen dalam jumlah yang kecil pada pemegang sahamnya. Temuan empiris ini berarti semakin tingginya debt to equity ratio, maka perusahaan farmasi lebih besar dialokasikan untuk laba ditahan yang disebabkan total kewajiban meningkat namun modal tetap atau peningkatan total kewajiban lebih besar dibandingkan peningkatan modal sehingga lebih besar laba ditahan untuk membiayai total kewajiban sehingga semakin kecil dividen yang dibayarkan kepada para pemegang saham.

\section{Pengaruh Earning Growth terhadap Dividend Payout Ratio}

Earning growth memengaruhi dividend payout ratio perusahaan farmasi secara negatif dan tidak signifikan terhadap dividend payout ratio. Hasil empiris yang berbeda dengan Amah (2012), Maladjian \& Khoury (2014) dan Zulkifli (2015) menyatakan bahwa growth berpengaruh negatif dan signifikan terhadap dividend payout ratio. Hasil empiris juga yang berbeda dengan Riyanto (2010) yang menyatakan salah satu faktor yang memengaruhi dividen yaitu tingkat pertumbuhan. Semakin cepat 


\section{Jurnal Keuangan dan Perbankan | KEUANGAN}

Vol. 21, No. 2, April 2017: 238-252

tingkat pertumbuhan suatu perusahaan, semakin besar kebutuhan akan dana untuk membiayai pertumbuhan tersebut. Semakin besar kebutuhan dana untuk waktu mendatang untuk membiayai pertumbuhannya, perusahaan tersebut biasanya lebih senang untuk menahan pendapatannya daripada membayarkan sebagai dividen para pemegang saham dengan mengingat batasan-batasan biayanya. Dengan demikian dapatlah dikatakan bahwa semakin cepat tingkat pertumbuhan perusahaan semakin besar dana yang dibutuhkan, semakin besar kesempatan untuk memperoleh keuntungan, semakin besar bagian dari pendapatan yang ditahan dalam perusahaan, berarti semakin rendah dividend payout ratio. Namun hasil empiris ini sama dengan Pribadi \& Sampurno (2012), Marietta (2013) dan Laim et al. (2015) menyatakan bahwa growth berpengaruh negatif dan tidak signifikan terhadap dividend payout ratio. Temuan empiris ini berarti semakin tingginya earning growth, maka perusahaan farmasi lebih besar laba ditahan untuk membiayai kebutuhan perusahaan, sehingga semakin kecil dividen yang dibayarkan kepada para pemegang sahamnya. Namun earning growth tidak memengaruhi secara signifikan karena pertumbuhan laba bagi perusahaan farmasi bukan sebagai pertimbangan pembayaran dividen.

\section{Pengaruh Return on Equity terhadap Dividend Payout Ratio}

Return on equity memengaruhi dividend payout ratio perusahaan farmasi secara negatif dan signifikan. Hasil empiris yang berbeda dengan Harianja et al. (2013), Yudhanto \& Aisjah (2013) dan Zulkifli (2015) menyatakan bahwa return on equity berpengaruh positif dan signifikan terhadap dividend payout ratio. Hasil empiris juga yang berbeda yang dinyatakan oleh Sartono (2010) bahwa return on equity merupakan ukuran profitabilitas dari sudut pandang pemegang saham. Salah satu alasan utama perusahaan beroperasi adalah meng- hasilkan laba yang bermanfaat bagi para pemegang saham. Semakin besar return on equity mencerminkan kemampuan perusahaan dalam menghasilkan keuntungan yang tinggi bagi pemegang saham yang berdampak terhadap peningkatan dividen. Namun hasil empiris sama dengan Maladjian \& Khoury (2014) menyatakan bahwa return on equity berpengaruh negatif dan signifikan terhadap dividend payout ratio. Temuan empiris ini berarti semakin tingginya return on equity dapat disebabkan laba bersih meningkat namun modalnya tetap atau peningkatan laba bersih lebih besar dibandingkan peningkatan modal, maka perusahaan farmasi lebih besar laba ditahan untuk dialokasikan kembali pada modal, maka semakin kecil dividen yang dibayarkan kepada para pemegang saham karena dengan meningkatkan modal, maka perusahaan dapat membiayai kebutuhan perusahaan yang merupakan dasar pertimbangan pemilik perusahaan lebih menguntungkan daripada dibayarkan dividen terlalu besar.

\section{Pengaruh Earning Per Share terhadap Dividend Payout Ratio}

Earning per share memengaruhi dividend payout ratio perusahaan farmasi secara positif dan tidak signifikan. Hasil empiris yang berbeda dengan Yudhanto \& Aisjah (2013), Saeed et al. (2014) dan Zulkifli (2015) menyatakan bahwa earning per share berpengaruh positif dan signifikan terhadap dividend payout ratio. Hasil empiris juga yang berbeda dengan Brigham \& Houston (2006) yang mengemukakan keterkaitan antara earning per share terhadap dividen yaitu earning per share merupakan rasio yang menunjukkan bagian laba untuk setiap saham. Earning per share menggambarkan profitabilitas perusahaan yang tergambar pada setiap lembar saham. Semakin tinggi nilai earning per share akan menyebabkan semakin besar laba dan kemungkinan peningkatan jumlah dividen yang diterima pemegang saham. Hal ini berarti semakin 


\section{Determinan Internal Dividend Payout Ratio Perusahaan Farmasi terdaftar di Bursa Efek Indonesia Zulkifli, Endri, Augustina Kurniasih}

tingginya earning per share yang disebabkan meningkatnya laba bersih mencerminkan keuntungan perusahaan dari penjualan bersih, maka perusahaan farmasi membayarkan dividen semakin besar kepada para pemegang saham. Namun earning per share tidak memengaruhi secara signifikan bukan sebagai pertimbangan pembayaran dividen sama halnya seperti pertumbuhan laba. Temuan empiris ini menunjukkan bahwa perusahaan farmasi lebih mempertimbangkan return on asset dan return on equity yang mengukur kemampuan perusahaan dalam menghasilkan laba bersih dari keseluruhan assets dan modal yang tersedia untuk menentukan dividen yang diterima bagi para pemegang saham.

\section{Pengaruh Market to Book Value terhadap Dividend Payout Ratio}

Market to book value memengaruhi dividend payout ratio perusahaan farmasi secara positif dan signifikan. Temuan empiris ini sejalan dengan studi Gill et al. (2010), Marpaung \& Hadianto (2009), dan Utami (2015) yang menunjukkan bahwa market to book value ratio memengaruhi dividend payout ratio secara positif. Hasil empiris ini juga sama dengan Sartono (2010) menyatakan bahwa nilai perusahaan yang tercermin pada harga pasar saham, harga saham mencerminkan laba potensial, perkembangan perusahaan, dividen, risiko perusahaan, struktur modal dan faktor lain seperti kualitas manajemen. Rasio penilaian pasar menunjukan berapa besar nilai perusahaan dari apa yang telah atau sedang ditanamkan oleh pemilik perusahaan, semakin tinggi rasio ini, maka semakin besar tambahan kekayaan (wealth) yang dinikmati oleh pemilik perusahaan (Husnan \& Pudjiastuti, 2006). Semakin tinggi market to book value, maka menunjukkan ekspektasi investor tentang prestasi perusahaan di masa yang akan datang cukup tinggi memiliki laba, sehingga memiliki kesempatan pembagian laba tinggi pula berupa dividen kepada para pemegang saham. (Harahap, 2008). Temuan empiris ini dengan peningkatan market to book value di- sebabkan karena terjadi peningkatan harga pasar saham meskipun nilai buku tetap atau peningkatan harga pasar saham lebih tinggi dibandingkan peningkatan nilai buku yang menyebabkan ekspektasi investor terhadap harga pasar saham semakin tinggi yang diikuti keyakinan investor bahwa perusahaan memiliki kemampuan menghasilkan laba bersih yang besar di masa akan datang. Peningkatan laba bersih diharapkan investor akan pembayaran dividen yang semakin besar

\section{SIMPULAN DAN SARAN}

\section{Simpulan}

Penelitian ini melakukan estimasi dan analisis determinan internal dividend payout ratio perusahaan farmasi yang tercatat di Bursa Efek Indonesia (BEI) selama periode 2008-2014. Estimasi dan analisis terhadap penelitian ini dengan menggunakan fixed effect yang memiliki nilai $\mathrm{R}$ square 0.857 lebih baik dibandingkan dengan pooled least squares dan random effect. Model penelitian ini mengestimasi dan menganalisis determinan internal yang memengaruhi dividend payout ratio yaitu current ratio, return on asset, debt to equity ratio, earning growth, return on equity, earning per share dan market to book value.

Current ratio memengaruhi dividend payout ratio perusahaan farmasi secara negatif dan signifikan. Temuan empiris ini tidak sesuai dengan hipotesis penelitian yang menyatakan bahwa variabel current ratio berpengaruh positif dan signifikan terhadap dividend payout ratio perusahaan farmasi yang tercatat di Bursa Efek Indonesia selama periode 2008-2014.

Return on assets memengaruhi dividend payout ratio perusahaan farmasi secara positif dan signifikan. Temuan empiris ini sesuai dengan hipotesis penelitian yang menyatakan bahwa variabel return on assets berpengaruh positif dan signifikan terhadap dividend payout ratio perusahaan farmasi yang tercatat di Bursa Efek Indonesia selama periode 


\section{Jurnal Keuangan dan Perbankan | KEUANGAN}

Vol. 21, No. 2, April 2017: 238-252

2008-2014. Disamping itu, variabel Return on assets merupakan faktor yang paling dominan memengaruhi dividend payout ratio perusahaan farmasi.

Debt to equity ratio memengaruhi dividend payout ratio perusahaan farmasi secara negatif dan signifikan. Temuan empiris ini sesuai dengan hipotesis penelitian yang menyatakan bahwa variabel debt to equity ratio berpengaruh negatif dan signifikan terhadap dividend payout ratio perusahaan farmasi yang tercatat di Bursa Efek Indonesia selama periode 2008-2014.

Earning growth memengaruhi dividend payout ratio perusahaan farmasi secara negatif, namun tidak signifikan. Temuan empiris ini tidak sesuai dengan hipotesis penelitian yang menyatakan bahwa variabel earning growth berpengaruh negatif dan signifikan terhadap dividend payout ratio perusahaan farmasi yang tercatat di Bursa Efek Indonesia selama periode $2008-2014$.

Return on equity memengaruhi dividend payout ratio perusahaan farmasi secara negatif dan signifikan. Temuan empiris ini tidak sesuai dengan hipotesis penelitian yang menyatakan bahwa variabel return on equity berpengaruh positif dan signifikan terhadap dividend payout ratio perusahaan farmasi yang tercatat di Bursa Efek Indonesia selama periode 2008-2014.

Earning per share memengaruhi dividend payout ratio perusahaan farmasi secara positif, namun tidak signifikan. Temuan empiris ini tidak sesuai dengan hipotesis penelitian yang menyatakan bahwa variabel earning per share berpengaruh positif dan signifikan terhadap dividend payout ratio perusahaan farmasi yang tercatat di Bursa Efek Indonesia selama periode 2008-2014.

Market to book value memengaruhi dividend payout ratio perusahaan farmasi secara positif dan signifikan. Temuan empiris ini sesuai dengan hipotesis penelitian yang menyatakan bahwa variabel market to book value berpengaruh positif dan signifikan terhadap dividend payout ratio perusahaan far- masi yang tercatat di Bursa Efek Indonesia selama periode 2008-2014.

\section{Saran}

Penelitian selanjutnya diarahkan untuk menambah variabel faktor eksternal karena temuan empiris ini menghasilkan nilai $R$-square 0.857 yang berarti variabel independen yang digunakan dalam penelitian ini dapat menjelaskan $85.7 \%$ terhadap dividend payout ratio. Jika menambahkan atau menggunakan faktor-faktor lain yang memengaruhi dividend payout ratio tidak hanya pada faktor internal saja tetapi juga menambahkan faktor-faktor eksternal perusahaan yaitu suku bunga, inflasi, nilai tukar dan pertumbuhan ekonomi, kemungkinan sisanya $14.3 \%$ dapat menjelaskan variasi kenaikan $R$-square sehingga dapat menghasilkan hasil penelitian yang lebih komprenshif.

Penelitian selanjutnya diarahkan untuk menggunakan sampel perusahaan yang lebih banyak seperti seluruh perusahaan manufaktur bukan hanya pada sub sektor perusahaan farmasi atau menggunakan sampel perusahaan pada sektor lain karena temuan empiris ini menghasilkan nilai $R$ square 0.857 yang berarti sampel perusahaan farmasi dapat menjelaskan $85.7 \%$. Jika menggunakan sampel perusahaan pada sektor lain, kemungkinan sisanya $14.3 \%$ dapat menjelaskan variasi kenaikan $R$-square sehingga dapat memberikan rekomendasi dan saran yang kuat bagi para pihak yang berkepentingan sehingga dapat memberikan temuan baru yang memperkuat, mengeneralisasi hasil temuan dan menjadi acuan bagi investor serta para akademisi untuk mengetahui kinerja keuangan perusahaan yang memengaruhi pembayaran dividen tunai.

\section{DAFTAR PUSTAKA}

Amah, Nik 2012. Faktor-Faktor yang Memengaruhi Dividend Policy Perusahaan go Public di Indonesia. ASSETS: Jurnal Akuntansi dan Pendidikan, (1)1: 4555. 


\section{Determinan Internal Dividend Payout Ratio Perusahaan Farmasi terdaftar di Bursa Efek Indonesia Zulkifli, Endri, Augustina Kurniasih}

Amidu, M. \& Abor, J. 2006. Determinants of Dividend Payout Ratios in Ghana, Journal of Risk Finance, 7(2): 136-45.

Brigham, E.F. \& Houston, J.F. 2006. Dasar-Dasar Manajemen Keuangan. Alih bahasa oleh Ali Akbar Yulianto. Edisi 10. Jakarta: Salemba Empat.

Gill, A., Biger, N., \& Tibrewala, R. 2010. Determinants of Dividend Payout Ratios: Evidence from United States. The Open Business Journal, 3: 08-14.

Goranova, M., Dharwadkar, R., \& Brandes. P. 2010. Owners on Both Sides of the Deal: Mergers and Acquisitions and Overlapping Institutional Ownership. Strategic Management Journal, 31(10): 1114-35.

Harahap, S.S. 2008. Analisis Kritis atas Laporan Keuangan. Edisi 1. Jakarta: Raja Grafindo Persada.

Halim, J.J. 2013. Faktor-Faktor yang Memengaruhi Kebijakan Dividen Perusahaan yang terdaftar di Bursa Efek Indonesia Pada Sektor Industri Barang Konsumsi Periode 2008-2011. Jurnal Ilmiah Mahasiswa Universitas Surabaya, 2(2): 1-19.

Hasan, M., Ahmad, M.I., Rafiq., M.Y., \& Rehman, R.U. 2015. Dividend Payout Ratio and Firm's Profitability: Evidence from Pakistan. Theoretical Economics Letters, 5(5): 441-445.

Harianja, H., Lubis, A.F., \& Torong, Z.B. 2013. Analisa Faktor-Faktor yang Memengaruhi Kebijakan Dividen dengan Cash Ratio sebagai Variabel Moderating pada Perusahaan Barang Konsumsi yang terdaftar di Bursa Efek Indonesia. Jurnal Telaah dan Riset Akuntansi, 6(2): 109-121.

Husnan, S. \& Pudjiastuti, E. 2006. Dasar-Dasar Manajemen Keuangan. Yogyakarta: UPP STIM YKPN.

Hutagalung, S., Yahya, M.H., Kamarudin, F., \& Osman, Z. 2013. The Dividend Payout Policy: A Study on Malaysian Financial Institution. Socials Sciences and Humanities, 21: 127-148.

Hossain, Md., Sheikh, F.R., \& Akterujjaman, S.M. 2014. Impact of Firm Specific Factors on Cash Dividend Payment Decisions: Evidence from Bangladesh. International Review of Business Research Papers, 10(2): $62-80$.

Kasmir. 2012. Analisis Laporan Keuangan. Cetakan Keenam. Jakarta: Raja Grafindo Persada.
Khalid, S., \& Rehman, M.U. 2015. Determination of Factors effecting the Dividend policy of Organizations. International Journal of Information, Business and Management, 8(3): 319- 333.

Odawo, C. \& Ntoiti, J. 2015. Determinants of Dividend Payout Policy in Public Ltd Banks In Kenya: A Case Study Of CFC Stanbic Bank. The Strategic Journal of Business and Change Management, 2(2): 182191.

Laim, W., Nangoy, S.C., \& Murni, S. 2015. Analisis FaktorFaktor yang Memengaruhi Dividend Payout Ratio pada Perusahaan yang Terdaftar di Indeks LQ45 Bursa Efek Indonesia. Jurnal Ekonomi, Bisnis dan Akuntansi, 3(1): 1129-1140.

Lenox, M. J., Rockart, S. F., \& Lewin. A.Y. 2010. Does Interdependency Affect Firm and Industry Profitability? An Empirical Test. Strategic Management Journal, 31(2): 121-139.

Lioew, M.A., Murni, S., \& Mandagie, Y. 2014. ROA, ROE, NPM Pengaruhnya terhadap Dividend Payout Ratio pada Perusahaan Perbankan dan Financial Institusi yang Terdaftar di BEI Periode 2010-2012. Jurnal Ekonomi, Bisnis dan Akuntansi, 2(2): 14061416.

Maladjian, C. \& Khoury, R.E. 2014. Determinants of the Dividend Policy: An Empirical Study on the Lebanese Listed Banks. International Journal Economics and Finance, 6(4): 240 -256.

Marietta, U. \& Sampurno, D. 2013. Analisis Pengaruh Cash Ratio, Return on Assets, Growth, Firm Size, Debt to Equity Ratio terhadap Dividend Payout Ratio (Studi pada Perusahaan Manufaktur yang Terdaftar di Bursa Efek Indonesia Tahun 20082011). Diponegoro Journal of Management, 2(3): 111.

Manneh, A.M. \& Naser, K. 2015. Determinants of Corporate Dividends Policy: Evidence from an Emerging Economy". International Journal Economics and Finance, Vol. VII, No,7, hal 229- 239.

Marpaung, I.E. \& Hadianto, B. 2009. Pengaruh Profitabilitas dan Kesempatan Investasi terhadap Kebijakan Dividen: Studi Empirik pada Emiten Pembentuk Indeks LQ45 di Bursa Efek Indonesia. Jurnal Akuntansi, 1(1): 70- 84. 


\section{Jurnal Keuangan dan Perbankan | KEUANGAN}

Vol. 21, No. 2, April 2017: 238-252

Marlina, L. \& Danica, C. 2009. Analisis Pengaruh Cash Position, Debt to Equity Ratio dan Return on Asset terhadap Dividend Payout Ratio. Jurnal Manajemen Bisnis, 2(1): 1-6.

Mertayani, S., Darmawan, A.S., \& Werastuti, S. 2015. Analisis Pengaruh Net Profit Margin, Debt Equity Ratio, Current Ratio dan Ukuran Perusahaan Terhadap Dividend Payout Ratio (Studi Kasus Pada Perusahaan Lq 45 yang Terdaftar di Bursa Efek Indonesia Periode 2009-2013). E-Journal S1 Ak Universitas Pendidikan Ganesha, 3(1): 1-13.

Omran, M. \& Pointon, J. 2004. Dividend Policy Trading Characteristics and Share Prices: Empirical Evidence From Egyptian Firms. Int. J. Theory Appl. Finance, 7: 121-30.

Pribadi, S.A. \& Sampurno, D. 2012. Analisis Pengaruh Cash Position, Firm Size, Growth Opportunity, Ownership, dan Return on Asset terhadap Dividend Payout Ratio. Diponegoro Journal of Management, 1(1): 212- 222.

Rahayuningtyas, S., Suhadak, \& Handayani, S.R. 2014. Pengaruh Rasio-Rasio Keuangan Terhadap Dividend Payout Ratio (DPR) (Studi pada Perusahaan yang Listing di BEI Tahun 2009 - 2011). Jurnal Administrasi dan Bisnis, 7(2): 1-9.

Rehman, A. \& Takumi, H. 2012. Determinants of Dividend Payout Ratio: Evidence From Karachi Stock Exchange (KSE). Journal of Contemporary Issues in Business Research, 1(1): 20-27.

Riyanto, B. 2010. Dasar- Dasar Pembelanjaan Perusahaan. Edisi 4. Yogyakarta: BPFE.

Saeed, R., Riaz, A., Lodhi, R.N., Munir, H.M., \& Iqbal, A. 2014. Determinants of Dividend Payouts in Financial Sector of Pakistan. Journal of Basic and Applied Scientific Research, 4(2): 33-42.

Sartono, A. 2010. Manajemen Keuangan: Teori dan Aplikasi. Edisi 4. Yogyakarta: BPFE.
Sutrisno. 2009. Manajemen Keuangan Teori, Konsep dan Aplikasi. Yogyakarta: Ekonisia.

Sunarya, H.D. 2013. Pengaruh Kebijakan Utang, Profitabilitas dan Likuiditas terhadap Kebijakan Dividen dengan Size sebagai Variabel Moderasi pada Sektor Manufaktur Periode 2008-2011. Jurnal Ilmiah Mahasiswa Universitas Surabaya, 2(1): 1-19.

Subramanyam, K.R. \& Wild, J. 2010. Analisis Laporan Keuangan. Salemba Empat. Jakarta.

Sundjaja, R. \& Barlin, I. 2010. Manajemen Keuangan. Edisi 6. Jakarta: Literata Lintas Media.

Syamsuddin, L. 2011. Manajemen Keuangan Perusahaan. Jakarta: Raja Grafindo Persada.

Utami, B.W. 2015. The Effectness of Investment Opportunity, Financing Company, Profitability, Cash, and Market to Book Value to Dividend Payment Policy (A Case Study of Manufacturing Company Listed In Indonesian Stock Exchange In 2008-2011). International Journal of Scientific Research and Education, 3(5): $3476-3494$.

Tong, T.W. \& Reuer, J.J. Firm and Industry Influences on the Value of Growth Options. 2006. Strategic Organization 4(1): 71-95.

Yudhanto, S. \& Aisjah, S. 2013. Pengaruh Net Profit Margin, Return on Asset, Return on Equity, Earning Per Share terhadap Kebijakan Dividen (Studi Pada Perusahaan Manufaktur yang terdaftar di Bursa Efek Indonesia). Jurnal Ilmiah Mahasiswa FEB, 1(2): 1-14.

Zulkifli. 2015. Effect of Current Ratio, Return on Asset, Debt to Equity Ratio, Earning Growth, Return on Equity and Earning Per Share For Dividend Payout Ratio Pharmaceutical Company Listed on The Indonesia Stock Exchange. Proceeding Indonesia International Conference on Business, Management And Communication. Makassar 27- 28 Agustus 2015. 